\title{
Endoscopic Treatment of Boerhaave Syndrome: A Case Report
}

\author{
Mustafa Salih Akın, ${ }^{1}$ Mehmet Sait Buğdacı, ${ }^{2}$ Esin Korkut ${ }^{1}$
}

\author{
'Department of Gastroenterology, \\ Medipol University Faculty of \\ Medicine, İstanbul, Turkey \\ ${ }^{2}$ Department of Gastroenterology, \\ İstinye University Liv Hospital, \\ İstanbul, Turkey \\ Submitted: 24.01.2018 \\ Accepted: 29.01.2018 \\ Correspondence: Esin Korkut, \\ Medipol Üniversitesi Tıp Fakültesi, \\ Gastroenteroloji Bilim Dalı, \\ İstanbul, Turkey \\ E-mail: ekorkut@medipol.edu.tr

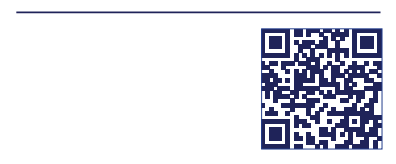 \\ Keywords: Boerhaave \\ syndrome; endoscopic clip; \\ endoscpic treatment.
}

\begin{abstract}
Boerhaave syndrome is a spontaneous perforation of the esophagus. It is associated with high morbidity and mortality. Boerhaave syndrome is a rare condition and there are limited evidence-based guidelines for management. Endoscopic methods have become more effective over time and in many cases reduced the need for surgery, as well as reducing morbidity and mortality. Endoscopic clips are increasingly used for procedures such as polypectomy, endoscopic submucosal dissection, or natural orifice transluminal endoscopic surgery for emergencies such as bleeding or perforation. Presently described is a case of Boerhaave Syndrome treated endoscopically.
\end{abstract}

\section{INTRODUCTION}

Boerhaave Syndrome is a spontaneous perforation of the esophagus associated with a sudden increase in intrathoracic pressure (i.e., severe retching or vomiting). The subtlety of the symptoms frequently contributes to a delay in diagnosis and poor prognosis. Esophageal perforations are rare, with an annual incidence of $3.1 / 1,000,000$ individuals. Nearly 15\% of esophageal perforations are spontaneous perforations. ${ }^{[1-3]}$

Boerhaave syndrome is generally seen in patients with a normal esophagus. However, a subgroup of patients has eosinophilic esophagitis, drug-related esophagitis, Barrett's esophagus or infectious ulcers. ${ }^{[4,5]}$

An esophageal perforation generally involves the left posterolateral aspect of the distal intrathoracic esophagus and is typically a few centimeters long. However, rupture may also emerge on the cervical or intra-abdominal esophagus. Rupture of the intrathoracic esophagus causes contam- ination of the mediastinal cavity with gastric content. It may lead to the development of mediastinal emphysema, chemical mediastinitis, subsequent bacterial infection, and mediastinal necrosis. If left untreated, sepsis and organ failure may occur. ${ }^{[6]}$

The clinical characteristics of Boerhaave syndrome depend on the location of the perforation (cervical, intrathoracic, or intra-abdominal), the degree of leakage, and the time elapsed since the injury. Frequently, retrosternal chest pain is seen. Crepitation may be heard on palpation of the chest wall due to the presence of subcutaneous emphysema. A few hours after the perforation, odynophagia, dyspnea, and sepsis may develop, and on physical examination, fever, tachypnea, tachycardia, cyanosis, and sepsis may be seen. Pleural effusion may also be detected. Laboratory tests may reveal leucocytosis. ${ }^{[7,8]}$

Boerhaave syndrome is often diagnosed incidentally in a patient who is evaluated for chest pain. The presence of severe chest, neck, or upper abdominal pain should raise 
the suspicion of subcutaneous emphysema on physical examination. Diagnosis can be made based on examination of esophagograms or computed tomography (CT) images. Delay in the diagnosis is associated with complications and a greater risk of mortality (16-51\%). ${ }^{[9]}$

The role of an upper endoscopy in the diagnosis of spontaneous perforation is controversial because both the endoscope and the insufflated air may increase the area of perforation. It should be performed by an experienced endoscopist and when surgical intervention can be readily performed in case of need. ${ }^{[10]}$

\section{CASE REPORT}

A 73-year-old female patient presented complaining of epigastric pain ongoing for nearly I year. The patient had been diagnosed with chronic lymphocytic leukemia 4 years earlier, and she had undergone gastric surgery 20 years earlier. For the previous month, she had experienced severe episodes of nausea and vomiting. A few hours before presentation at the clinic, she had expelled bright red vomitus and experienced chest pain. Endoscopy was planned in the intensive care unit. During the endoscopic examination, the previous gastric operation site (Billroth II partial gastrectomy), a seemingly malignant mass on the anastomotic site, past which the endoscope could be advanced distally, and an area of perforation on the distal part of the esophagus were observed (Fig. Ia and b).

The area of perforation was closed with an endoscopic clip (Fig. Ic and d).
After the procedure, oral and intravenous contrast-enhanced thoracic and abdominal CT images were obtained. Multiple lymphadenopathies were observed on the bilateral supraclavicular, axillary, mediastinal, bilateral hilar, and paraaortic areas, the interaortocaval area, and at the level of celiac trunk, diffuse pathological thickness of the gastric wall, the clip applied to the esophagogastric junction, millimetric free air bubbles, and minimal free fluid in the perigastric area in the vicinity of the greater curvature were seen. Extraesophageal contrast leakage was not detected (Fig. le).

Febrile episodes or chest pain did not develop during follow-up. On the second postoperative day, nutrition with oral fluid intake was initiated. The endoscopic biopsy result was reported as adenocarcinoma. A positron emission tomography/CT was performed. Intensely increased metabolic activity in the primary lesion in the stomach, multiple conglomerated abdominal lymphadenopathies, and multiple suspect nodular lesions suggesting implants were observed in the omentum and abdomen. The patient was evaluated by the Department of General Surgery and the Department of Oncology, and was considered an inoperable case. An endoscopic examination with contrast material injection under fluoroscopy performed 3 days later did not reveal any leakage of contrast material. The patient was discharged 4 days after her hospitalization without any additional clinical or laboratory abnormalities.

\section{DISCUSSION}

Since esophageal perforation has a high mortality rates, all patients should be closely monitored. Irrespective of
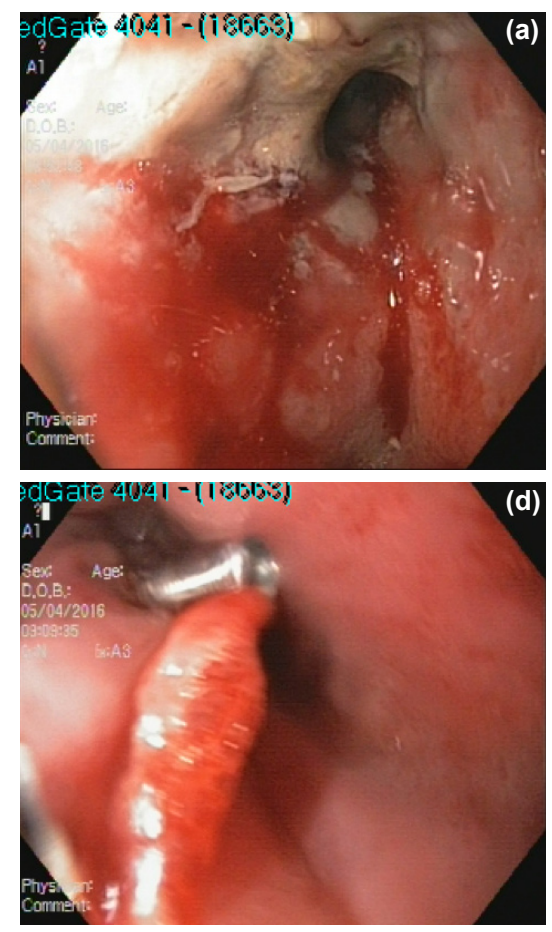
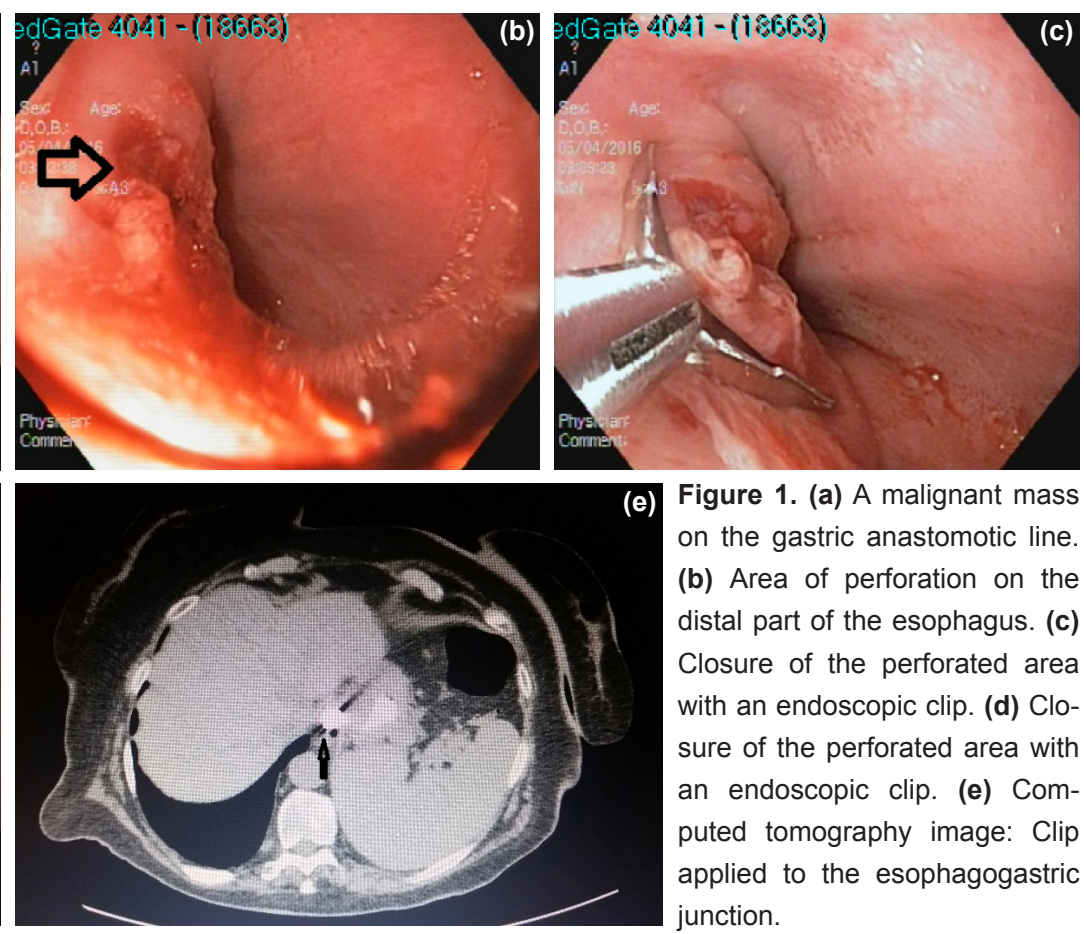

e) Figure 1. (a) A malignant mass on the gastric anastomotic line. (b) Area of perforation on the distal part of the esophagus. (c) Closure of the perforated area with an endoscopic clip. (d) Closure of the perforated area with an endoscopic clip. (e) Computed tomography image: Clip applied to the esophagogastric junction. 
the treatment approach used (medical, endoscopic, or surgical), oral (parenteral nutrition) intake should be terminated in all patients with esophageal perforation, and intravenous broad-spectrum antibiotics and intravenous proton pump inhibitors should be administered. If present, fluid collection should be drained, and infected, necrotic tissue should be debrided. Since patients treated using medical or endoscopic means may require surgical treatment, surgical consultation should be performed.

Management of the patients depends on the size and location of the perforation between the mediastinal and visceral pleura, how soon it is diagnosed, and any underlying morbidities.

Patients who manifest symptoms and signs of clinical worsening during medical treatment should undergo surgical intervention. Surgery is indicated in any of the following conditions: ${ }^{[1,12]}$

I. Patients who develop free diffuse extravasation,

2. Enlargement of the perforation,

3. Clinical worsening, persistent fever, or sepsis (percutaneous drainage should be performed if possible),

4. Progression of pneumomediastinum or pneumothorax, or

\section{Development of empyema.}

Endoscopic treatment should be considered in patients with underlying significant comorbidities who cannot tolerate surgery. ${ }^{[13]}$ Endoscopic treatment has not been directly compared with surgery in the management of Boerhaave syndrome in randomized studies; however, observational studies have demonstrated the need for reintervention in a substantial number of these patients managed with endoscopic treatment. In a systematic review of 340 patients with esophageal perforation, the success rate of endoscopic stenting was $81 \%$ and 58 (I7\%) patients required endoscopic reintervention. Surgical interventions were performed in $33(10 \%)$ patients..$^{[14]}$ In a retrospective study, the clinical outcomes of 13 patients managed with endoscopic stenting and 20 patients who had undergone surgery were compared. No intergroup difference was found with regard to morbidity, hospitalization, or intensive care stay, and II of I 3 stented patients required surgical intervention. ${ }^{[13]}$

A minimally invasive treatment that uses over-the-endoscope clips (OTSC) for the closure of perforations located on the esophagogastric junction has also been described. ${ }^{[15]}$

Though nonoperative endoscopic transesophageal debridement of a mediastinal abscess appears to be a safe and effective method, further studies are needed. In a prospective series, 8 patients with a paraesophageal abscesses (abscess $>2 \mathrm{~cm}$ and sepsis) secondary to Boerhaave syndrome were treated using an endoscopic ultra- sound-guided mediastinal puncture. ${ }^{[16]}$ Debridement was successful in all cases, however, within 2 to 8 days, repeat drainage was required. Esophageal defects were closed using endoclips, fibrin adhesives, or metal stents. Alternatively, OTSC can be used to close the defect with a standard endoscopic clip. ${ }^{[17]}$ Fibrin has been used as a filling and sealing material in the management of chronic esophagobronchial fistula. ${ }^{[8]}$

In patients with underlying comorbidities who cannot tolerate surgery, endoscopic treatment of an esophageal perforation should be considered. A significant portion of patients managed with endoscopic treatment require further treatment. As was the case with this patient, in eligible cases, endoscopic clips can be used. However, case series are needed to establish the validity, reliability, and safety of this method.

Informed Consent

Approval was obtained from the patients.

Peer-review

Internally peer-reviewed.

Authorship Contributions

Concept: M.S.A., M.S.B., E.K.; Design: M.S.A., M.S.B., E.K.; Data collection \&/or processing: M.S.A., M.S.B., E.K.; Analysis and/or interpretation: M.S.A., M.S.B., E.K.; Literature search: M.S.A., M.S.B., E.K.; Writing: M.S.A., M.S.B., E.K.; Critical review: M.S.A., M.S.B., E.K.

Conflict of Interest

None declared.

\section{REFERENCES}

1. Brauer RB, Liebermann-Meffert D, Stein HJ, Bartels H, Siewert JR. Boerhaave's syndrome: analysis of the literature and report of 18 new cases. Dis Esophagus 1997;10:64-8. [CrossRef]

2. Vidarsdottir H, Blondal S, Alfredsson H, Geirsson A, Gudbjartsson T. Oesophageal perforations in Iceland: a whole population study on incidence, aetiology and surgical outcome. Thorac Cardiovasc Surg 2010;58:476-80. [CrossRef]

3. Brinster CJ, Singhal S, Lee L, Marshall MB, Kaiser LR, Kucharczuk JC. Evolving options in the management of esophageal perforation. Ann Thorac Surg 2004;77:1475-83. [CrossRef]

4. Pate JW, Walker WA, Cole FH Jr, Owen EW, Johnson WH. Spontaneous rupture of the esophagus: a 30-year experience. Ann Thorac Surg 1989;47:689-92. [CrossRef]

5. Herbella FA, Matone J, Del Grande JC. Eponyms in esophageal surgery, part 2. Dis Esophagus 2005;18:4-16. [CrossRef]

6. Michel L, Grillo HC, Malt RA. Operative and nonoperative management of esophageal perforations. Ann Surg 1981;194:57-63. [CrossRef]

7. McGovern M, Egerton MJ. Spontaneous perforation of the cervical oesophagus. Med J Aust 1991;154:277-8.

8. Wilson RF, Sarver EJ, Arbulu A, Sukhnandan R. Spontaneous perforation of the esophagus. Ann Thorac Surg 1971;12:291-6. [CrossRef]

9. Larsen K, Skov Jensen B, Axelsen F. Perforation and rupture of the esophagus. Scand J Thorac Cardiovasc Surg 1983;17:311-6. 
10. Gubbins GP, Nensey YM, Schubert TT, Batra SK. Barogenic perforation of the esophagus distal to a stricture after endoscopy. J Clin Gastroenterol 1990;12:310-2. [CrossRef]

11. Ivey TD, Simonowitz DA, Dillard DH, Miller DW Jr. Boerhaave syndrome. Successful conservative management in three patients with late presentation. Am J Surg 1981;141:531-3. [CrossRef]

12. Carrott PW Jr, Low DE. Advances in the management of esophageal perforation. Thorac Surg Clin 2011;21:541-55. [CrossRef]

13. Schweigert M, Beattie R, Solymosi N, Booth K, Dubecz A, Muir $A$, et al. Endoscopic stent insertion versus primary operative management for spontaneous rupture of the esophagus (Boerhaave syndrome): an international study comparing the outcome. Am Surg 2013;79:634-40.

14. Dasari BV, Neely D, Kennedy A, Spence G, Rice P, Mackle E, et al. The role of esophageal stents in the management of esophageal anastomotic leaks and benign esophageal perforations. Ann Surg 2014;259:852-60. [CrossRef]

15. Braun A, Richter-Schrag HJ, Fischer A, Hoeppner J. Minimally invasive therapy of perforations at the esophagogastric junction by overthe-scope clipping. Endoscopy 2013;45 Suppl 2 UCTN:E133-4.

16. Wehrmann T, Stergiou N, Vogel B, Riphaus A, Köckerling F, Frenz MB. Endoscopic debridement of paraesophageal, mediastinal abscesses: a prospective case series. Gastrointest Endosc 2005;62:3449. [CrossRef]

17. Kobara H, Mori H, Rafiq K, Fujihara S, Nishiyama N, Kato K, et al. Successful endoscopic treatment of Boerhaave syndrome using an over-the-scope clip. Endoscopy 2014;46 Suppl 1 UCTN:E82-3.

18. Harries K, Masoud A, Brown TH, Richards DG. Endoscopic placement of fibrin sealant as a treatment for a long-standing Boerhaave's fistula. Dis Esophagus 2004;17:348-50. [CrossRef]

\section{Boerhaave Sendromunun Endoskopik Tedavisi: Olgu Sunumu}

Boerhaave sendromu, özofagusun spontan perforasyonudur. Yüksek morbidite ve mortalite ile ilişkilidir. Boerhaave sendromu nadir bir durumdur ve tedavisi için kanıta dayalı kılavuzlar sınırıdır. Tedavisinde endoskopik ve cerrahi yöntemler kullanılmaktadır. Endoskopik yöntemler zamanla daha etkin hale gelmekte ve birçok durumda cerrahiye ihtiyacı, morbidite ve mortaliteyi azaltmaktadır. Endoskopik klipler hem kanama hem de perforasyon gibi acil durumlar için, polipektomi, endoskopik submukozal diseksiyon (ESD) veya NOTES (Natural Orifice Transluminal Endoscopic Surgery) gibi prosedürlerde giderek daha yaygın olarak kullanılmaktadır. Bu yazıda, endoskopik olarak tedavi edilen Boerhaave sendromlu bir olgu sunuldu.

Anahtar Sözcükler: Boerhaave sendromu; endoskopik klip; endoskopik tedavi. 